\title{
RETINAL LASER PHOTOCOAGULATION IN MANAGEMENT OF EALES' DISEASE
}

Takhchidi KhP, Takhchidi EKh, Kasminina TA, Tebina EP $\bowtie$, Mokrunova MV

Pirogov Russian National Medical Research University, Moscow, Russia

\begin{abstract}
Eales' disease is an idiopathic occlusive inflammatory vasculopathy resulting in peripheral retinal ischemia, neovascularization, recurrent hemophthalmos, and proliferative tissue formation. It is often complicated by tractional retinal detachment, secondary glaucoma, and central retinal vein occlusion. The management of patients with Eales' disease includes mainly glucocorticosteroid therapy, the use of angiogenesis inhibitors, vitreoretinal surgery and laser photocoagulation. The clinical case reported demonstrates the potential of retinal laser photocoagulation for treatment of the Eales' disease in the ischemic and proliferative stages. The results of retinal laser photocoagulation used as monotherapy demonstrate the clinical and functional indices improvement: enhanced visual acuity, stabilized central retinal sensitivity value, restored clarity to the ocular media, regression of neovascularization and macular edema in the patient's eye being in the proliferative (3b) stage, and the process stabilization in the eye being in the ischemic (2a) stage of the disease.
\end{abstract}

Keywords: Eales' disease, laser photocoagulation, optical coherence tomography, fluorescein angiography

Author contribution: Takhchidi KhP — study concept and design, manuscript editing; Takhchidi EKh — literature analysis; Tebina EP — manuscript writing; Kasminina TA — laser treatment; Mokrunova MV — data acquisition and processing

Compliance with ethical standards: the patient submitted informed consent to laser treatment and personal data processing.

$\triangle$ Correspondence should be addressed: Ekaterina P. Tebina

Volokolamskoe shosse, 30, str. 2, Moscow, 123182; ekaterinatebina@mail.ru

Received: 20.09.2020 Accepted: 12.10.2020 Published online: 23.10.2020

DOI: $10.24075 /$ brsmu.2020.063

\section{ПРИМЕНЕНИЕ ЛАЗЕРНОЙ КОАГУЛЯЦИИ СЕТЧАТКИ ПРИ БОЛЕЗНИ ИЛЗА}

\author{
Х. П. Тахчиди, Е. Х. Тахчиди, Т. А. Касмынина, Е. П. Тебина $凵$, М. В. Мокрунова
}

Российский национальный исследовательский медицинский университет имени Н. И. Пирогова, Москва, Россия

\begin{abstract}
Болезнь Илза - идиопатическая окклюзионная воспалительная васкулопатия, которая приводит к периферической ишемии сетчатки, неоваскуляризации, рецидивирующим гемофтальмам, развитию пролиферативной ткани и нередко осложняется тракционной отслойкой сетчатки, вторичной глаукомой, окклюзией центральной вены сетчатки. В основном при ведении пациентов с данной патологией используют глюкокортикостероидную терапию, ингибиторы ангиогенеза, витреоретинальную хирургию и лазерную коагуляцию. Представленный клинический случай демонстрирует возможность использования лазерной коагуляции сетчатки при лечении болезни Илза на ишемической и пролиферативной стадиях. Полученные результаты применения лазерной коагуляции сетчатки в качестве монотерапии свидетельствуют об улучшении клиникофункциональных показателей: увеличении остроты зрения, стабилизации показателя центральной светочувствительности сетчатки, восстановлении прозрачности оптических сред, регрессе неоваскуляризации и макулярного отека на глазу с пролиферативной стадией (3b), а также стабилизации процесса на глазу в стадии ишемии (2а).
\end{abstract}

Ключевые слова: болезнь Илза, лазерная коагуляция, оптическая когерентная томография, флюоресцентная ангиография

Вклад авторов: Х. П. Тахчиди — концепция и дизайн исследования, редактирование текста; Е. Х. Тахчиди — анализ литературных данных; Е. П. Тебина написание текста; Т. А. Касмынина — лазерное лечение пациента; М. В. Мокрунова — сбор и обработка материала.

Соблюдение этических стандартов: от пациента получено согласие на лазерное лечение и обработку персональных данных

$\checkmark$ Для корреспонденции: Екатерина Павловна Тебина

Волоколамское шоссе, д. 30, корп. 2, г. Москва, 123182; ekaterinatebina@mail.ru

Статья получена: 20.09.2020 Статья принята к печати: 12.10.2020 Опубликована онлайн: 23.10.2020

DOI: 10.24075 /vrgmu.2020.063

Eales' disease is an idiopathic occlusive inflammatory vasculopathy, which results in peripheral retinal ischemia, neovascularization, recurrent hemophthalmos and proliferative tissue formation [1, 2].

The literature indicates that the disorder is most common in healthy young males in their second decade of life, and in 90\% of patients both eyes are affected [3].

The disorder was first described by British ophthalmologist Henry Eales in 1880 [4]. Etiopathogenesis of the Eales' disease is not completely understood. In recent years, as a result of immunological, molecular biological and biochemical studies, the role of human leukocyte antigen, autoimmune mechanisms, Mycobacterium tuberculosis and free radicals in the disease pathogenesis has been shown $[5,6]$. The natural course of the disease is quite variable, with alternating periods of remission and exacerbation $[7,3]$.

According to the literary sources, the disorder usually presents with involvement of peripheral retina and is characterized by a number of manifestations of varying intensity: inflamed veins, ischemia and retinal neovascularization. The listed above manifestations often result in the following complications: recurrent retinal and vitreous hemorrhages, traction/rhegmatogenous retinal detachment, rubeosis iridis and secondary glaucoma [8]. In some cases, central retina is affected, which results in macular edema [9].

The "gold standard" in the Eales' disease detection is fluorescein angiography (FA) allowing one to assess blood flow and damage to retinal blood vessels: dye transudation, retinal vascular tortuosity and telangiectasia, vascular shunt, venous stasis, ischemia, retinal neovascularization [10-12].

In 2007, the new Eales' disease classification was proposed based on the ophtalmoscopy and FA data [13].

Stage 1

(1a) Periphlebitis of small caliber vessels

(1b) Periphlebitis of large caliber vessels with superficial retinal hemorrhages 

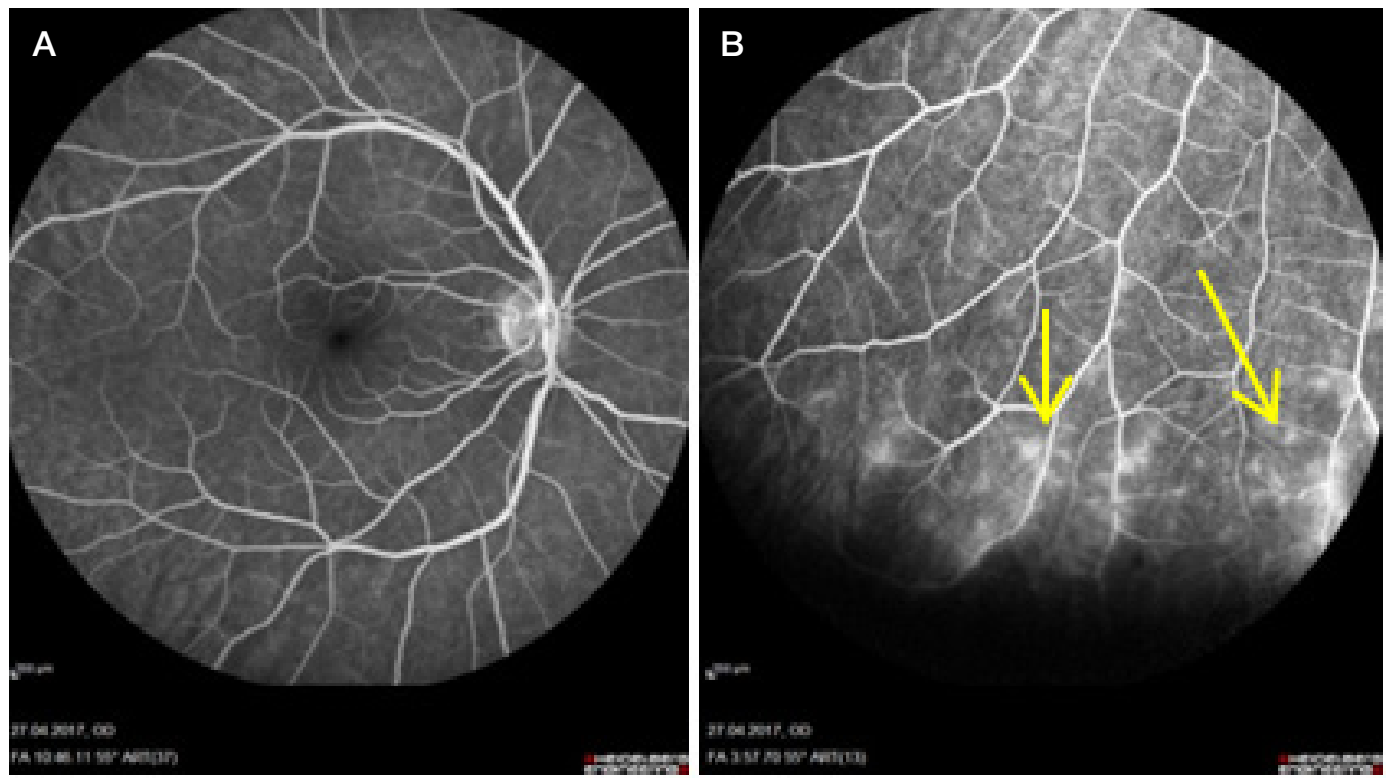

Fig. 1. FA, right eye. A. Optic disc with sharp margins, vascular calibers not altered, AN ratio 2/3, normal macular area. B. Dye extravasation and aneurisms are visualized in the area of altered blood vessels in the peripheral fundus (yellow arrow)

\section{Stage 2}

(2a): Capillary nonperfusion

(2b): Neovascularization of the disc and/or retina

Stage 3

(3a): Fibrovascular proliferation

(3b): Hemophthalmos

Stage 4

(4a): Traction and/or rhegmatogenous retinal detachment

(4b): Rubeosis iridis, neovascular glaucoma, complicated cataract, optic atrophy

The current diagnosis procedures together with wide range of treatment options significantly improve the Eales' disease prognosis and outcome [3, 7]. The management tactics depends on the stage of the disease [14-20] and includes the following: taking glucocorticosteroids (systemic and/or periocular) in the stage of inflammation [7]; intravitreal injection of angiogenesis inhibitor [16]; vitreoretinal surgery (in patients with recurrent hemophthalmos, vitreoretinal traction and/or retinal detachment) [21].

Laser photocoagulation is one of the first-line therapeutic options for Eales' disease in the ischemic and proliferative stages [3, 15, 16, 19-22]. According to the foreign authors, regression of retinal neovascularization and vitreoretinal traction after laser photocoagulation is detected in $80-90 \%$ of patients [16, 23-25]. Moreover, bilateral photocoagulation in the ischemic areas of asymptomatic eyes is an effective measure for prevention of the Eales' disease complications [16, 26]. In this case study we attempted to assess the effectiveness and safety of retinal laser photocoagulation for management of Eales' disease in the ischemic (2a) and proliferative (3b) stages.

\section{Clinical case}

Patient A., aged 20, complaining of floaters and decreased visual acuity in his left eye contacted the Scientific Research Center for Ophthalmology of Pirogov Russian National Medical Research University. It was also known from his case history that the described manifestations emerged spontaneously and persisted for six months. The patient seeked medical assistance from ophthalmologist at his place of residence, and was diagnosed with uveitis of unknown etiology in both eyes. He received conservative management, which included administration of glucocorticosteroids. No response to treatment was observed.
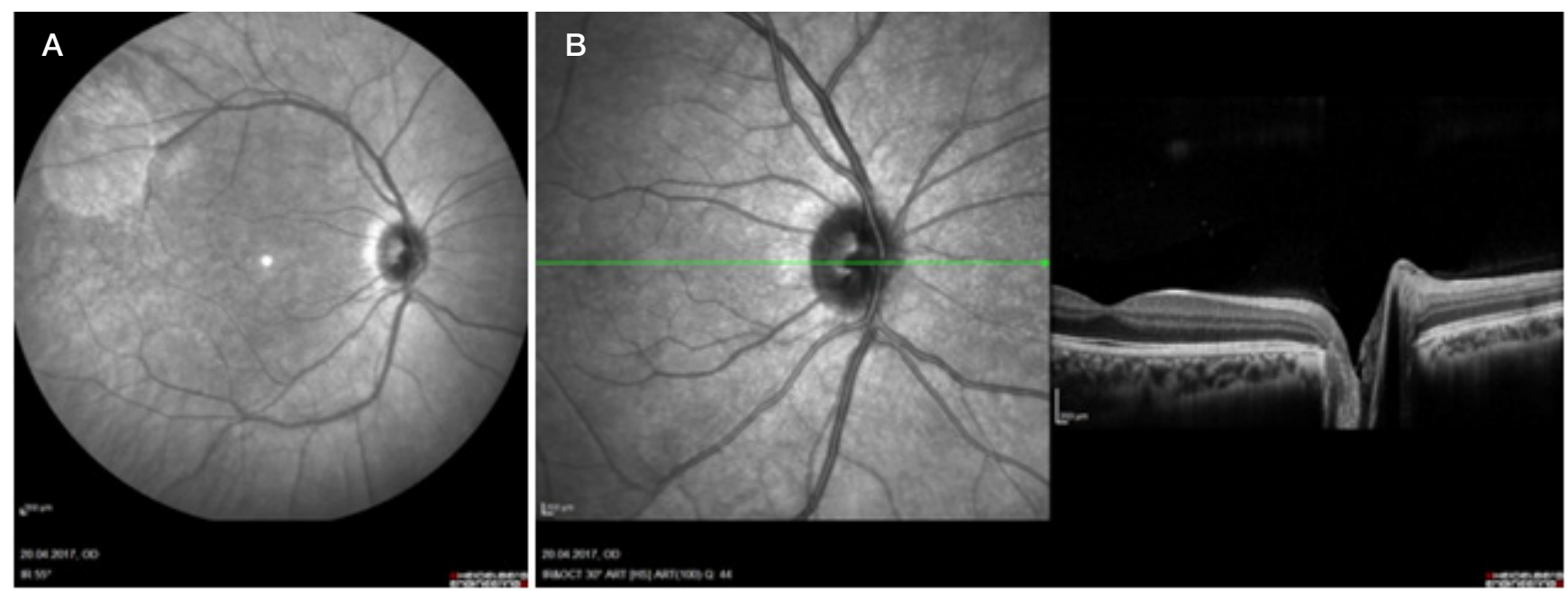

Fig. 2. A. IR reflectance image of fundus, right eye. Optic disc with sharp margins, normal macular area. B. OCT scan of the right eye. Cross-section image with normal optic disc and macular area 

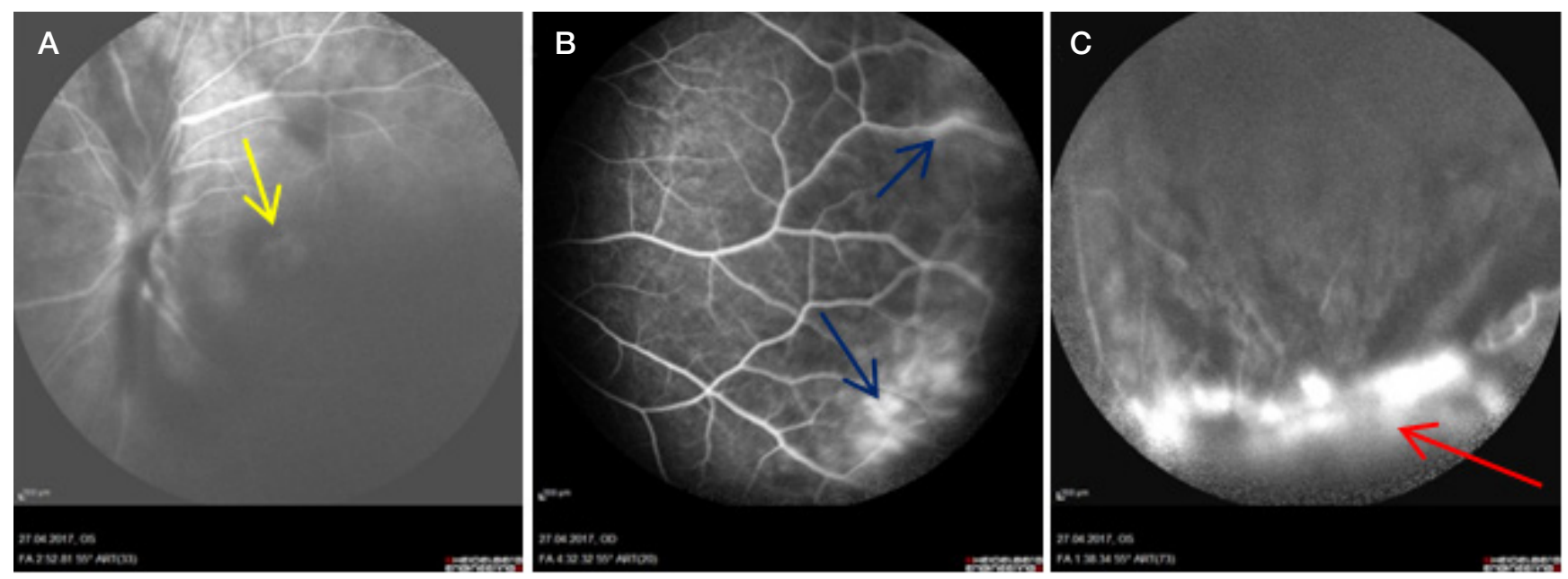

Fig. 3. FA, left eye. A. Optic disc with blurry margins; altered vascular caliber, petaloid (flower-like) pattern of hyperfluorescence is visible through hemophtalmos in central retina (yellow arrow). B. Periphlebitis with dye extravasation across the visible periphery (blue arrows). C. Protruding proliferative lesion with blurry margins visualized as a dense hyperfluorescent focus in the clock hour sector 5 (red arrow); hypofluorescent areas corresponding to hemorrhagic foci

The patient underwent complex assessment by the following methods: visometry aimed at determining the best corrected visual acuity (BCVA), ophthalmoscopy using the MaxField 78D lens (Ocular Inc.; USA), fluorescein angiography (FA) and spectral domain optical coherence tomography (SDOCT) imaging using the Spectralis HRA+OCT, OCT2 platform with a scanning speed of 85,000 Hz (Heidelberg Engineering; Germany), computer perimetry using the Humphrey Field Analyzer II (Carl Zeiss Meditec Inc.; USA) and the 30-2 SITAStandard test, computer microperimetry and assessment of central light sensitivity using the MAIA system (CenterVue Inc.; Italy). The patient had normal chest $\mathrm{x}$-ray and negative Mantoux test. Serology testing revealed no changes. The patient did not associate the onset of the disease with anything, and he had no hereditary taint. Laser photocoagulation was performed using the VISULAS Trion laser workstation working in the 532 nm mode (Carl Zeiss; Germany).

At initial examination, the BCVA in the right eye (OD) was 1.0, and in the left eye (OS) it was 0.1. Biomicroscopy OU revealed no pathological changes in the anterior segment of both eyes.

Ophthalmoscopy OD revealed pale-pink optic disc with sharp margins, normal macular reflex. Pathological reflex was detected in the paravasal area, the artery to vein (AN) ratio was $2 / 3$. Aneurysmal dilations and ischemic lesions were observed in peripheral retina. The venous phase FA detected contrast media extravazation and ischemic lesions in the area of altered vasculature involving the full circumference of the peripheral retina (Fig. 1). SDOCT revealed normal macular profile, structured retinal layers, and retinal thickness of $310 \mu \mathrm{m}$ (Fig. 2).

Vizualization during ophthalmoscopic examination OS was hampered by partial hemophthalmos. The optic disc was hyperemic, blurry, and protruded into the vitreous chamber. There was a fibrous cord over the optic disc extending to the inferior outer quadrant of the retina, the macular area was blurry. The veins were dilated and tortuous. In peripheral retina, there was a protruding lesion with blurry margins, retinal and preretinal hemorrhages in the clock hour sector 5. The venous phase FA detected the hyperfluorescent optic disc. The petaloid (flower-like) pattern of hyperfluorescence (macular edema) was observed in the central retina. Hyperfluorescent focus with hypofluorescent areas was detected on the periphery in the lower sector (Fig. 3). SDOCT revealed the retinal thickness increase up to $600 \mu \mathrm{m}$ in the macular area, and cystic cavities in the outer and inner nuclear layers (Fig. 4).
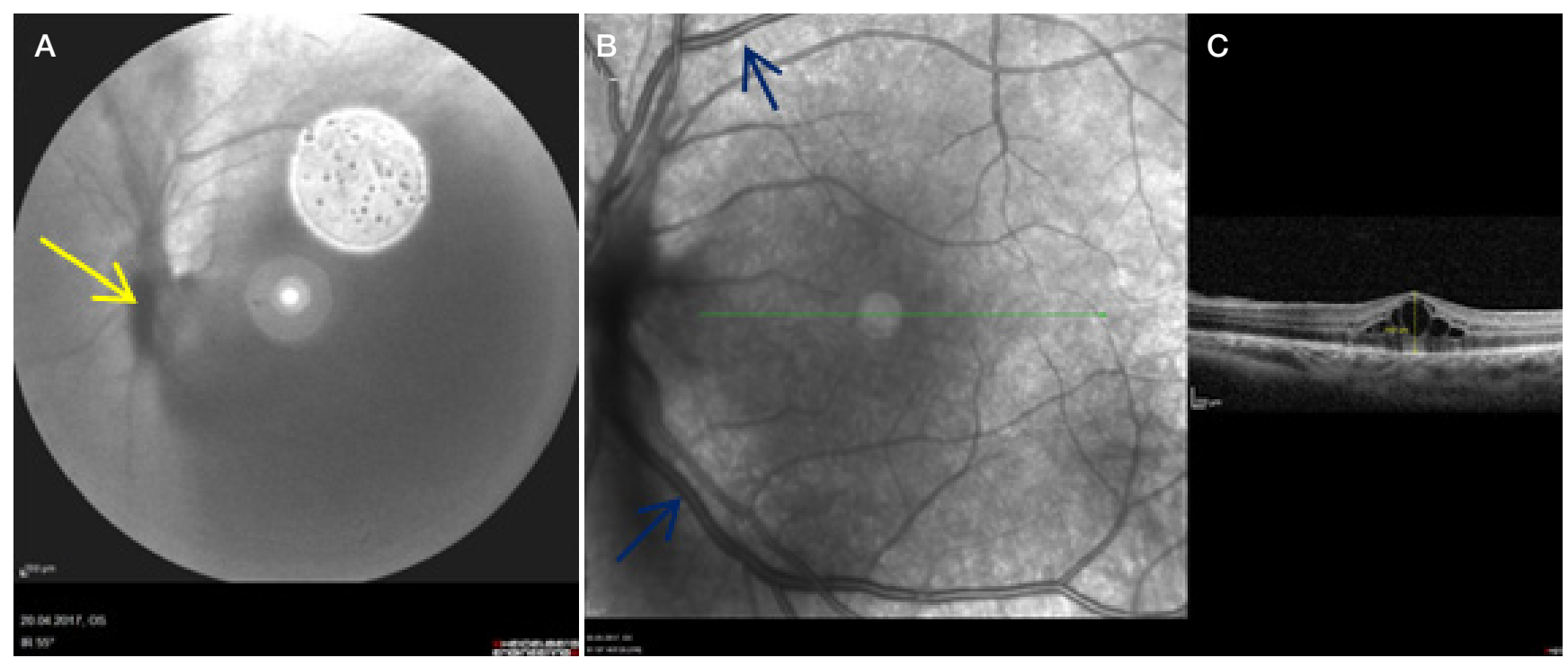

Fig. 4. A. IR reflectance image of fundus, left eye: partial hemophthalmos, fibrous cord over the optic disc extending to the inferior outer quadrant of the retina (yellow arrow). B. IR reflectance image of fundus, left eye: retinal veins dilated and tortuous (b/ue arrows). C. Macula OCT scan, left eye: cystoid edema $600 \mu \mathrm{m}$ 


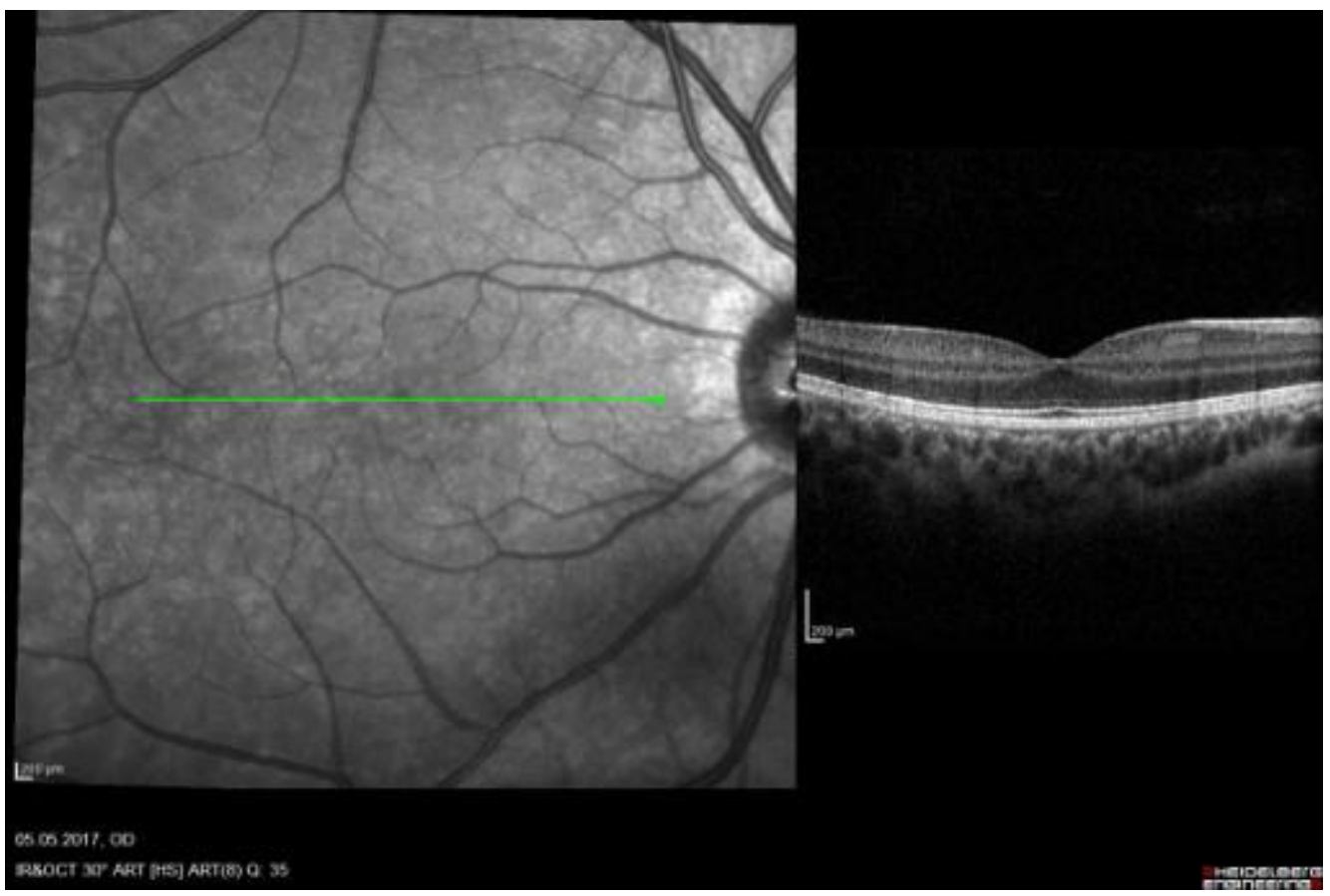

Fig. 5. Macula OCT scan, right eye: normal macular profile, structured retinal layers; no signs of clinical worsening have been revealed within the one month follow-up period

Taking into account the complaints, medical history and complex ophthalmological assessment data, the patient was diagnosed with Eales'disease, stage $2 a$ (ischemic areas detected by FA), OD, and stage 3b (proliferation and hemophthalmos), OS.

We agreed to perform laser photocoagulation. The extent of coagulation was determined by the amount of damage to retina. In OD (stage 2a) the extensive laser photocoagulation of the peripheral retina was performed (single session), in OS (stage 3b) the panretinal photocoagulation (four sessions at monthly intervals) was carried out. The following energy parameters were used in OD: the power was $100 \mathrm{~mW}$, the exposure time was $0.1 \mathrm{~s}$, the spot size was $200 \mu \mathrm{m}$, the distance between the spots was $300 \mu \mathrm{m}$, and the total number of burns was 500 . The following energy parameters were used in OS: the power was 100-120 mW, the exposure time was $0.1 \mathrm{~s}$, the spot size was $200 \mu \mathrm{m}$, the distance between the spots was $300 \mu \mathrm{m}$, and the total number of burns was 3,000. The following energy parameters were used for central retina in OS: the power was 50-100 mW, the exposure time was 0.05-0.1 s, the spot size was $100 \mu \mathrm{m}$, and the distance between the spots was $150 \mu \mathrm{m}$.

After a month of treatment BCVA OD was 1.0, and BCVA OS had increased to 0.7. Ophthalmoscopy OD revealed palepink optic disc with sharp margins. The retinal $A V$ ratio was $2 / 3$. The macular anatomy was intact. Pigmented coagula were observed across the peripheral retina, aneurysms and ischemic lesions were sealed (Fig. 5). Examination OS revealed declined hemophtalmos; the optic disc was pale-pink with sharp margins; the fibrous cord became smaller. The AN ratio was $2 / 3$. Partial regression of macular edema and lightly pigmented coagula were detected in the central retina (except the avascular zone). Pigmented coagula were revealed in the peripheral retina, the protruding lesion was sealed (Fig. 6).

After two years BCVA OU was 1.0. Biomicroscopy OU revealed no pathological changes in the anterior segment, the ocular media were clear.
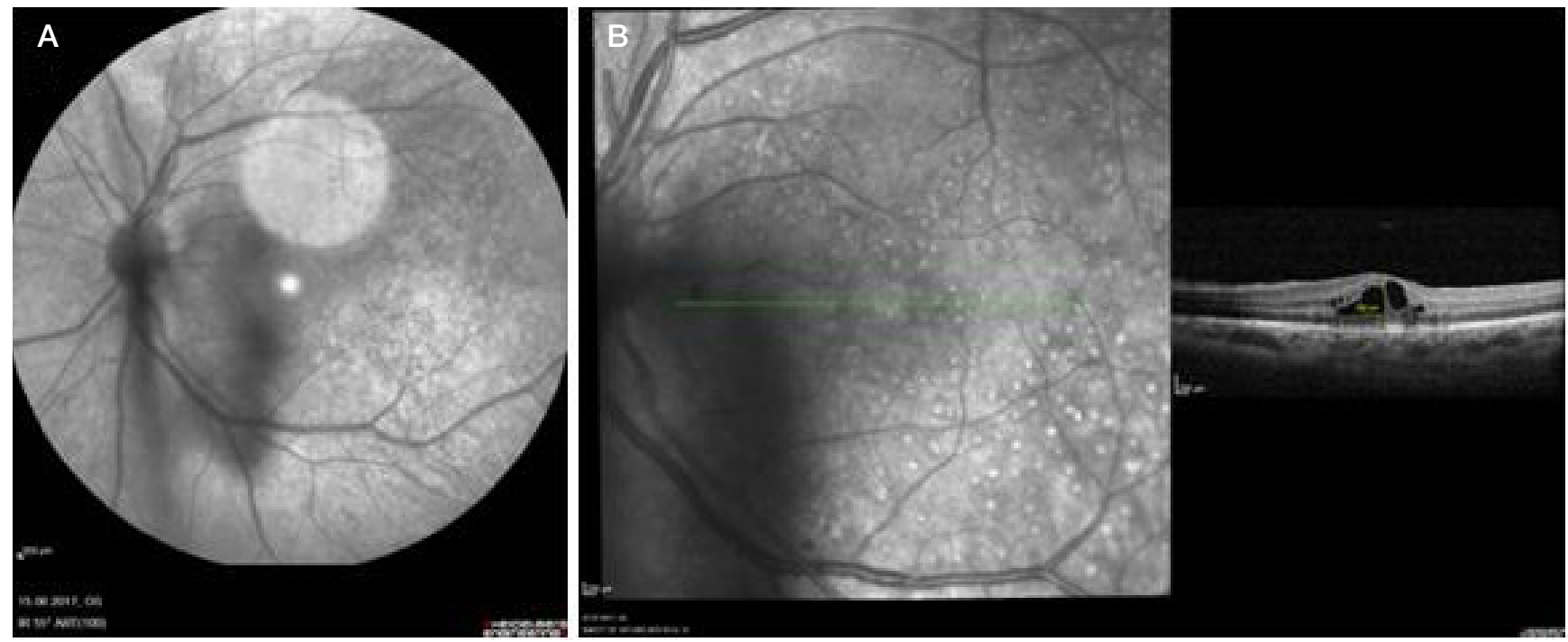

Fig. 6. A. IR reflectance image of fundus, left eye: declined hemophtalmos detected during a one month follow-up visit. B. Macula OcT scan, left eye: macular edema reduced from 600 to $500 \mu \mathrm{m}$ 


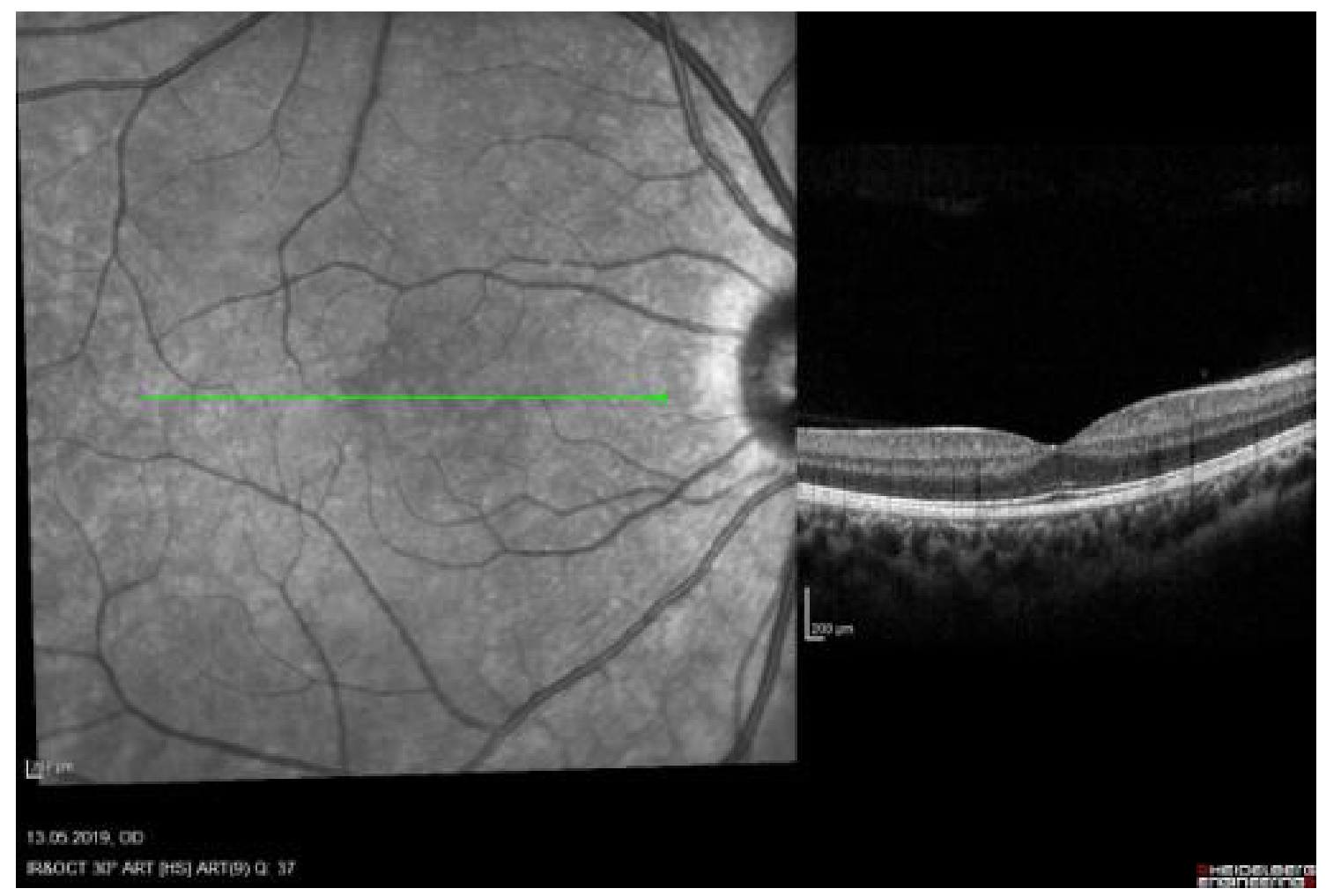

Fig. 7. Macula OCT scan, right eye: normal macular profile, structured retinal layers; no signs of clinical worsening have been revealed during the 2-year follow-up period

SDOCT detected no signs of clinical worsening in OD (Fig. 7). Ophthalmoscopy revealed pigmented coagula with sharp margins in the peripheral retina, no new lesions were observed. The central retinal sensitivity was $25.7 \mathrm{~dB}$.

Ophthalmoscopy OS revealed pale-pink optic disc with sharp margins, the fibrous cord over the optic disc became smaller. The retinal AN ratio was $2 / 3$. There were lightly pigmented coagula in the macular area (except the avascular zone). SDOCT detected restored macular profile, and regression of edema (Fig. 8). The fibrotic neovascularization focus with sharp margins was observed in the peripheral retina (Fig. 9). Pigmented coagula were detected in the paravasal area and across the peripheral retina. The central retinal sensitivity value was $25.4 \mathrm{~dB}$.

Computer perimetry OU revealed no visual field deficits.

\section{Discussion}

Successful implementation of laser photocoagulation as monotherapy for patients not responsive to glucocorticosteroids

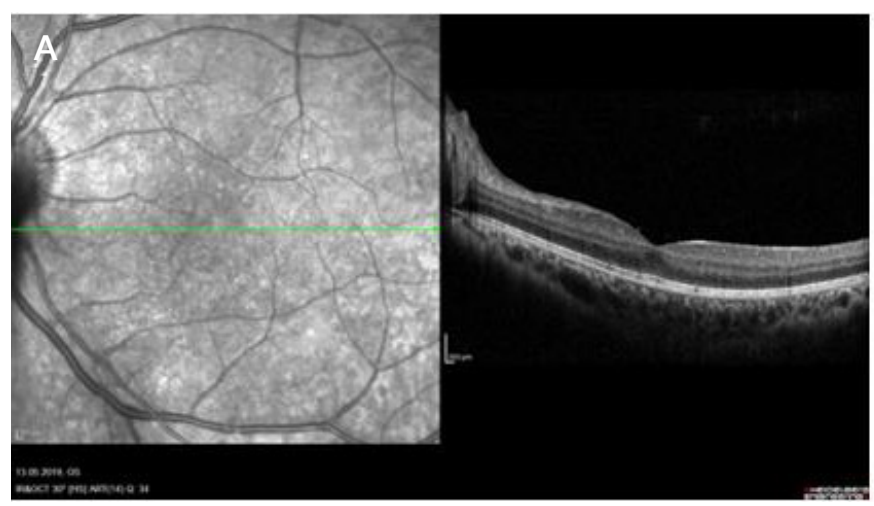

was reported by many foreign [14, 27] and national authors [28, 29]. However, the energy parameters of laser treatment play a vital part in the prognosis of the disease. The use of "rigid" retinal laser photocoagulation may result in complications, such as exudative retinal detachment, iatrogenic choroidal neovascularization, cystoid macular edema, epiretinal fibrosis, visual field deficits, deterioration in color vision and decline in contrast sensitivity [30-32]. According to literary sources, the most commonly used spot size is $400-500 \mu \mathrm{m}$, and the proposed pulse duration is $0.15-0.2 \mathrm{~s}$ with an interpulse interval of 0.15-0.3 s [3]. Similar energy parameters have been used in other studies: spot size of $400 \mu \mathrm{m}$, pulse duration of $0.15 \mathrm{~s}$, and the individually adopted average power value of 160-200 mW [28, 29].

In this study, in contrast to the international experience, we performed laser photocoagulation using the smaller spot size $(200 \mu \mathrm{m})$, lower power (100-120 mW) and exposure time of $0.1 \mathrm{~s}$ in order to improve the clinical and functional treatment results in patient with Eales' disease. The retinal laser photocoagulation safety in patient with stage $2 a$ (ischemic) and

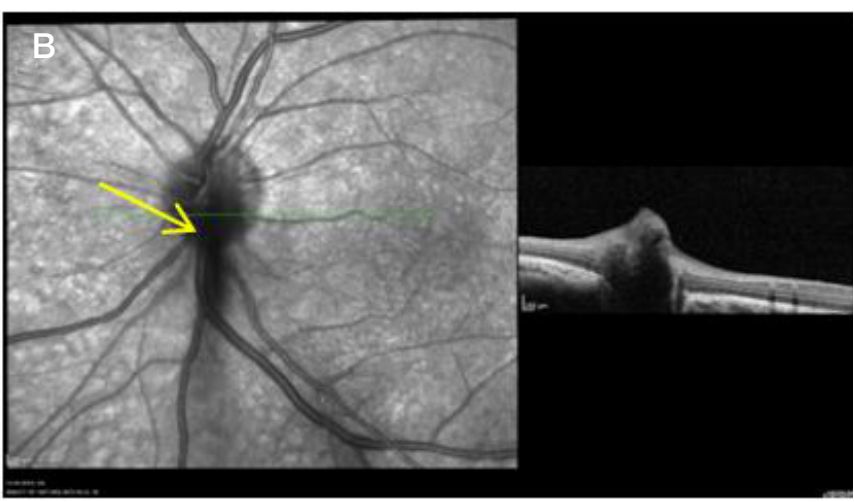

Fig. 8. A. Macula OCT scan, left eye: regression of cystoid macular edema, restored anatomic structure of retinal layers. B. Optic disc OCT, left eye: persisting fibrous cord over the optic disc (yellow arrow) 
3b (proliferative) Eales' disease and preserved retinal function were confirmed by advanced diagnosis methods: computer perimetry (no visual field deficits), computer microperimetry (preserved central retinal sensitivity), and optical coherence tomography imaging (regression of cystoid macular edema).

The proposed energy parameters made it possible to obtain good clinical and functional results within the long-term postoperative period, including the improved BCVA, stabilized central retinal sensitivity value, restored clarity to the ocular media, regression of neovascularization and macular edema in the eye being in the proliferative (3b) stage, and the process stabilization in the eye being in the ischemic (2a) stage of the disease.

\section{CONCLUSION}

The results obtained suggest that the use of retinal laser photocoagulation as monotherapy for patients with Eales' disease in the ischemic (2a) and proliferative (3b) stages contributes to the improvement of clinical and functional treatment results, and the late fate of laser treatment shows long-term remission.

\section{References}

1. Therese KL, Deepa P, Therese J, Bagyalakshmi R, Biswas J, Madhavan HN. Asso-ciation of mycobacteria with Eales' disease. Indian J Med Res. 2007; 126: 56-62.

2. Yannuzzi LA. The Retinal Atlas. Retinal Vascular Diseases, Eales Disease. Elsevier. 2010: 433-8.

3. Das T, Pathengay A, Hussain N, Biswas J. Eales' disease: diagnosis and management. Eye. 2010; 24 (3): 472-82.

4. Eales H. Retinal haemorrhages associated with epistaxis and constipation. Brim Med. 1880; 9: 262.

5. Madhavan HN, Therese KL, Doraiswamy K. Further investigations on the association of Mycobacterium tuberculosis with Eales disease. Indian J Ophthalmol. 2002; 50: 35-39.

6. Patwardhan SD, Azad E, Shah BM, Sharma Y. Role of intravitrea bevacizumab in Eales disease with dense vitreous haemorrhage: a prospective randomized control study. Retina. 2011; 31 (5): 866-70.

7. Biswas J, K R R, Pal B, Gondhale HP, Kharel Sitaula R. LongTerm Outcomes of a Large Cohort of Patients with Eales' Disease. Ocul Immunol Inflamm. 2018; 26 (6): 870-6.

8. Sen A, Paine SK, Chowdhury $\mathbb{H}$, Mukherjee A, Choudhury S, Mandal LK, Bhattacharya B. Assessment of gelatinase and tumor necrosis factor-alpha level in the vitreous and serum of patients with Eales disease; role of inflammation-mediated angio-genesis in the pathogenesis of Eales disease. Retina. 2011; 31 (7): 1412-20.

9. Saxena S, Kumar D. Macular involvement in Eales disease. Ann Ophthalmol. 2000; 32 (2): 98-100.

10. Gupta V, Al-Dhibi HA, Arevalo JF. Retinal imaging in uveitis. Saudi J Ophthalmol. 2014; 28: 95-103.

11. Kumar V, Chandra P, Kumar A. Ultra-wide field angiography in the management of Eales disease. Indian J Ophthalmol. 2016; 64: 504-7.

12. Mwndoza KA, Lauer A. Eales Disease. American Academy of Ophthalmology. 2015. Available from: http://eyewiki.org/Eales_ Disease.

13. Saxena S, Kumar D. New classification system-based visual outcome in Eales'disease. Indian J Ophthalmol. 2007; 55 (4): 267-9.

14. Biswas J, Ravi RK, Naryanasamy A, Kulandai LT, Madhavan HN. Eales' disease - current concepts in diagnosis and management. J Ophthalmic Inflamm Infect. 2013; 3: 11.

15. Das TP, Namperumalsamy P. Photocoagulation in Eales' disease. Results of pro-spective randomised clinical study. Presented in

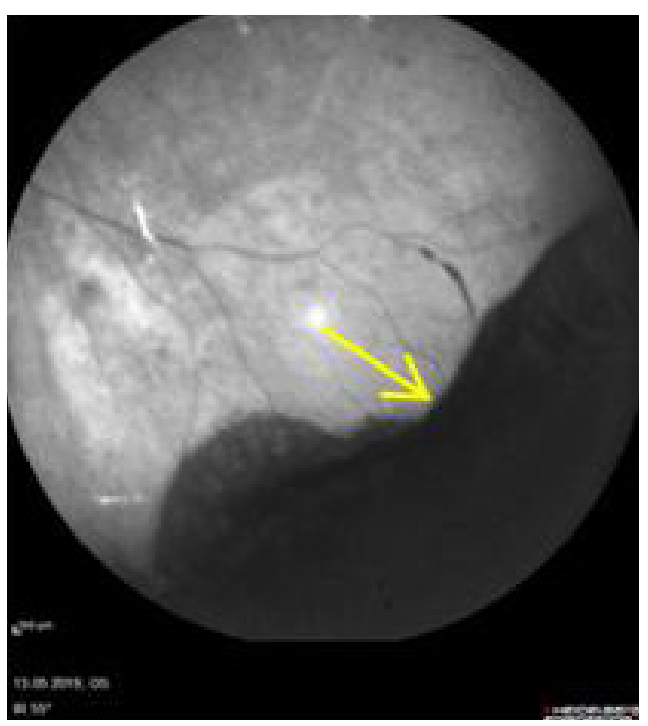

Fig. 9. IR - reflectance image of fundus, left eye: fibrotic neovascularization focus with sharp margins visualized in the clock hour sector 5 of peripheral retina (yellow arrow)

XXVI Int Cong Ophthalmol - Singapore, 1990

16. Ishaq M, Niazi MK. Usefulness of laser photocoagulation in managing asymptomatic eyes of Eales disease. J Ayub Med Coll Abbottabad. 2002; 14 (4): 22-25.

17. Ishaq M, Feroze AH, Shahid M, Baig MA, Ameen SS, Feroze SH, Chishti RA. Intravitreal steroids may facilitate treatment of Eales disease (idiopathic retinal vasculitis): an interventional case series. Eye (Lond). 2007; 21: 1403-5.

18. Kumar A, Sinha S. Rapid regression of disc and retinal neovascularization in a case of Eales disease after intravitreal bevacizumab. Can J Ophthalmol. 2007; 42 (2): 335-6.

19. Magargal LE, Walsh AW, Magargal HO, et al. Treatment of Eales' disease with scat-ter laser photocoagulation. Ann Ophthalmol. 1989; 21: 300-2.

20. Talat L, Lightman S, Tomkins-netzer O. Ischemic retinal vasculitis and its manage-ment. J Ophthalmol. 2014; 2014: 197675.

21. Li J, Liu SM, Dong WT, Li F, Zhou CH, Xu XD, Zhong J. Outcomes of transconjunctival sutureless 27-gauge vitrectomy for vitreoretinal diseases. Int J Ophthalmol. 2018; 11 (3): 408-15.

22. El-Asrar AM, Al-Kharashi SA. Full panretinal photocoagulation and early vitrectomy improve prognosis of retinal vasculitis associated with tuberculoprotein hypersensitivity (Eales' disease). Br J Ophthalmol. 2002; 86 (11): 1248-51.

23. Dehghan $\mathrm{MH}$, Ahmadieh $\mathrm{H}$, Soheilian M, Azarmina M, Mashayekhi A, Naghibozakerin J. Therapeutic effects of laser photocoagulation and/or vitrectomy in Eales' disease. Eur J Ophthalmol. 2005; 15 (3): 379-83

24. Gopal L, Abraham C. Efficacy of photocoagulation in Eales' disease. Trans Asia-Pacific Acad. 1985; 10: 689.

25. Nada M, Qanoongo S, Singh SV, Khurana AK. A rare presentation of exudative macroaneurysms in unilateral Eales' disease. Nepal J Ophthalmol. 2017; 9 (18): 95-98.

26. Murphy RP, Gieser SC, Fine SL, et al. Retinal and vitreous findings in Eales disease. Invest Ophthalmol Vis Sci. 1986; 27: 121.

27. Nicolcescu A, Mocanu C, Dinu L, Olaru A, lonete M, Stefanescu DA. Unilateral Eales' disease a case report. Rom J Ophthalmol. 2017; 61 (2): 144-9.

28. Pedanova EK, Burjakov DA. Jeffektivnost' lazerkoaguljacii pri bolezni Ilza v svete sovremennyh predstavlenij ob jetiopatogeneze zabolevanija. Sovremennye tehnologii lechenija vitreoretinal'noj patologii - 2013. 2013: 136. Available from: https://eyepress.ru/ article.aspx?12646. Russian. 
29. Tolstuhina EA, Magaramov DA, Volodin PL, Timohov VL, Fomin AV. Lazer-inducirovannyj regress perifericheskoj retinal'noj neovaskuljarizacii pri bolezni Ilza (klinicheskij sluchaj). Sovremennye tehnologii v oftal'mologii. 2019; 1 (26): 381-3. Russian.

30. Mainster MA. Decreasing retinal photocoagulation damage: principles and techniques. Semin Ophthalmol. 1999; 14 (4): 200-9.
31. Moutray T, Evans JR, Lois N, Armstrong DJ, Peto T, AzuaraBlanco A. Different lasers and techniques for proliferative diabetic retinopathy. Cochrane Database Syst Rev. 2018; 3 (3): CD012314.

32. Reddy SV, Husain D. Panretinal Photocoagulation: A Review of Complications. Semin Ophthalmol. 2018; 33 (1): 83-88.

\section{Литература}

1. Therese KL, Deepa P, Therese J, Bagyalakshmi R, Biswas J, Madhavan HN. Asso-ciation of mycobacteria with Eales' disease. Indian J Med Res. 2007; 126: 56-62.

2. Yannuzzi LA. The Retinal Atlas. Retinal Vascular Diseases, Eales' Disease. Elsevier. 2010: 433-8.

3. Das T, Pathengay A, Hussain N, Biswas J. Eales' disease: diagnosis and management. Eye. 2010; 24 (3): 472-82.

4. Eales H. Retinal haemorrhages associated with epistaxis and constipation. Brim Med. 1880; 9: 262.

5. Madhavan HN, Therese KL, Doraiswamy K. Further investigations on the association of Mycobacterium tuberculosis with Eales' disease. Indian J Ophthalmol. 2002; 50: 35-39.

6. Patwardhan SD, Azad E, Shah BM, Sharma Y. Role of intravitreal bevacizumab in Eales disease with dense vitreous haemorrhage: a prospective randomized control study. Retina. 2011; 31 (5): 866-70.

7. Biswas J, K R R, Pal B, Gondhale HP, Kharel Sitaula R. LongTerm Outcomes of a Large Cohort of Patients with Eales' Disease. Ocul Immunol Inflamm. 2018; 26 (6): 870-6.

8. Sen A, Paine SK, Chowdhury $\mathbb{H}$, Mukherjee A, Choudhury S, Mandal LK, Bhattacharya B. Assessment of gelatinase and tumor necrosis factor-alpha level in the vitreous and serum of patients with Eales disease; role of inflammation-mediated angio-genesis in the pathogenesis of Eales disease. Retina. 2011; 31 (7): 1412-20.

9. Saxena S, Kumar D. Macular involvement in Eales disease. Ann Ophthalmol. 2000; 32 (2): 98-100.

10. Gupta V, Al-Dhibi HA, Arevalo JF. Retinal imaging in uveitis. Saud J Ophthalmol. 2014; 28: 95-103.

11. Kumar V, Chandra P, Kumar A. Ultra-wide field angiography in the management of Eales disease. Indian J Ophthalmol. 2016; 64: $504-7$.

12. Mwndoza KA, Lauer A. Eales Disease. American Academy of Ophthalmology. 2015. Available from: http://eyewiki.org/Eales_ Disease.

13. Saxena S, Kumar D. New classification system-based visual outcome in Eales'disease. Indian J Ophthalmol. 2007; 55 (4): 267-9.

14. Biswas J, Ravi RK, Naryanasamy A, Kulandai LT, Madhavan HN. Eales' disease - current concepts in diagnosis and management. J Ophthalmic Inflamm Infect. 2013; 3: 11.

15. Das TP, Namperumalsamy P. Photocoagulation in Eales' disease. Results of pro-spective randomised clinical study. Presented in XXVI Int Cong Ophthalmol - Singapore, 1990.

16. Ishaq M, Niazi MK. Usefulness of laser photocoagulation in managing asymptomatic eyes of Eales disease. J Ayub Med Coll Abbottabad. 2002; 14 (4): 22-25.

17. Ishaq M, Feroze AH, Shahid M, Baig MA, Ameen SS, Feroze SH, Chishti RA. Intravitreal steroids may facilitate treatment of Eales' disease (idiopathic retinal vasculitis): an interventional case series.

Eye (Lond). 2007; 21: 1403-5.

18. Kumar A, Sinha S. Rapid regression of disc and retinal neovascularization in a case of Eales disease after intravitreal bevacizumab. Can J Ophthalmol. 2007; 42 (2): 335-6.

19. Magargal LE, Walsh AW, Magargal HO, et al. Treatment of Eales' disease with scat-ter laser photocoagulation. Ann Ophthalmol. 1989; 21: 300-2.

20. Talat L, Lightman S, Tomkins-netzer O. Ischemic retinal vasculitis and its manage-ment. J Ophthalmol. 2014; 2014: 197675.

21. Li J, Liu SM, Dong WT, Li F, Zhou CH, Xu XD, Zhong J. Outcomes of transconjunctival sutureless 27-gauge vitrectomy for vitreoretinal diseases. Int J Ophthalmol. 2018; 11 (3): 408-15.

22. El-Asrar AM, Al-Kharashi SA. Full panretinal photocoagulation and early vitrectomy improve prognosis of retinal vasculitis associated with tuberculoprotein hypersensitivity (Eales' disease). Br J Ophthalmol. 2002; 86 (11): 1248-51.

23. Dehghan MH, Ahmadieh H, Soheilian M, Azarmina M, Mashayekhi A, Naghibozakerin J. Therapeutic effects of laser photocoagulation and/or vitrectomy in Eales' disease. Eur J Ophthalmol. 2005; 15 (3): 379-83.

24. Gopal L, Abraham C. Efficacy of photocoagulation in Eales' disease. Trans Asia-Pacific Acad. 1985; 10: 689.

25. Nada M, Qanoongo S, Singh SV, Khurana AK. A rare presentation of exudative macroaneurysms in unilateral Eales' disease. Nepal $J$ Ophthalmol. 2017; 9 (18): 95-98.

26. Murphy RP, Gieser SC, Fine SL, et al. Retinal and vitreous findings in Eales disease. Invest Ophthalmol Vis Sci. 1986; 27: 121.

27. Nicolcescu A, Mocanu C, Dinu L, Olaru A, lonete M, Stefanescu DA. Unilateral Eales' disease a case report. Rom J Ophthalmol. 2017; 61 (2): 144-9.

28. Педанова Е. К., Буряков Д. А. Эфффективность лазеркоагуляции при болезни Илза в свете современных представлений об этиопатогенезе заболевания. Современные технологии лечения витреоретинальной патологии - 2013. 2013: 136. Доступно по ссылке: https://eyepress.ru/article.aspx?12646.

29. Толстухина Е. А., Магарамов Д. А., Володин П. Л., Тимохов В. Л., Фомин А. В. Лазер-индуцированный регресс периферической ретинальной неоваскуляризации при болезни Илза (клинический случай). Современные технологии в офттальмологии. 2019; 1 (26): 381-3.

30. Mainster MA. Decreasing retinal photocoagulation damage: principles and techniques. Semin Ophthalmol. 1999; 14 (4): 200-9.

31. Moutray T, Evans JR, Lois N, Armstrong DJ, Peto T, AzuaraBlanco A. Different lasers and techniques for proliferative diabetic retinopathy. Cochrane Database Syst Rev. 2018; 3 (3): CD012314.

32. Reddy SV, Husain D. Panretinal Photocoagulation: A Review of Complications. Semin Ophthalmol. 2018; 33 (1): 83-88. 